\title{
One-Way Street or Roundabout? German Migration Trajectories to and from Australia Since 1952
}

\author{
Maren Klein \\ PhD candidate \\ School of Languages, Cultures \& International Studies, Faculty of Business \& Enterprise \\ Swinburne University of Technology, Melbourne, Australia \\ mklein@swin.edu.au
}

Doi:10.5901/ajis.2013.v2n8p438

\begin{abstract}
Australia has been a country of immigration since becoming an independent nation in 1901. Until the 1970s the country's immigration program was predominantly European in origin, geared towards permanent settlement of skilled and also unskilled workers. Changes to Australia's migration program since the 1970s have seen diversification of country of origin, an increased focus on skills and economic growth, and since the mid-1990s a move towards temporary migration.Germany has been an important migrant source for Australia for more 200 years. Large scale German immigration was part of Australia's post-war era population policy and took place from 1952 until the late 1960s. German settler migrants in Australia, dubbed "the hidden migrants", were largely invisible due to their rapid assimilation. Despite a considerable decline in migrant numbers, Germany is still one of the ten most common countries of birth and ancestry in Australia, and ranks in the top 10 source countries for temporary immigration. However, today as in the past outflow of long-term German residents from Australia is significant. Moreover, technological advances in transportation and communications have made circularity a common phenomenon, making the distinction between permanent and temporary migration increasingly vague. This presentation will focus on aspects, processes and determinants of German migration and return behaviour since 1952 in the context of changing macro-level socio-spatial conditions.
\end{abstract}

Keywords: Migration, temporary migration, return migration

\section{Introduction}

"Australia is a country of arrivals and departures (Jupp, 1996, p. 1)."

This statement by James Jupp, one of Australia's foremost migration reseachers of the last 40 years, holds as true today as it did in 1966. According to data from the 2011 Australian Census, 5.3 million or 27 per cent of the resident population were born overseas (Australian Bureau of Statistics (ABS), 2012). It is commonly accepted knowledge that migration-voluntary or involuntary, assisted or self-financed-has been at the core of Australia's population and economic growth. It has been argued that Australia is the "product of conscious social engineering to create a particular kind of society" (Jupp, 2007, p. 5), "one of the few nations to have been built by planned immigration ... aimed at responding to labour market and economy needs" (Markus, Jupp, McDonald, 2009, p. 152). The authors also contend that the Australian Government's stringent control of the migration program is at the root of the public's general acceptance of immigration in Australia.

Until the 1970s Australia's migrant pool was overwhelmingly white, of Anglo-Saxon and, to a lesser extent, NorthWestern European origin. Among the North-Western European migrants, Germans have been an important group for more than 200 years. They were the first 'non-British' ethnic group of influence in the development of a number of Australian colonies, and despite a considerable decline in migrant numbers, Germany is still one of the ten most common countries of birth and ancestry in Australia, and ranks in the top 10 source countries for temporary immigration. However, today as in the past outflow of long-term German residents from Australia is significant.

The following section will provide a brief overview of Australia's migration history inclusive of German migration to and from Australia. Section 2 will review statistical data relating to German migration and return to and from Australia. Section 3 will discuss issues associated with investigating and analysing return migration. Section 4 will present information on data collection and some preliminary results of the investigation into German migration to and return behaviour from Australia since 1952 in the context of changing macro-level socio-spatial conditions. Section 5 concludes. 


\section{Australia's immigration history - brief overview}

The establishment of a British penal colony in New South Wales in 1788 laid the foundations for the development of what has been called "a white settler society, closely linked to Britain, and integrated into the economic system of the Empire" (Vasta, 2006, p. 18). The number of convicts of predominantly British and Irish origin transported to Australia between 1788 and 1868 has been estimated at approximately 160,000 persons. Free settlement, initially negligible, started to increase with the establishment of a pastoral economy in the early nineteenth century (Borrie, 1954). To encourage more settlers to Australia, assisted passage schemes subsidising the migrant's journey, were offered from 1832 (Richards, 2008). As a result approximately 61,000 again predominantly British and Irish immigrants arrived in Australia between 1836 and 1846. Among these a small number of other European immigrants of German and Italian origin were also present.

According to Tampke (2006), German history in Australia dates back as far as 1788; however, the first substantial wave of German immigration to Australia commenced in 1838 with the assisted passage and settlement in rural South Australia of a group of 180 Lutheran Germans fleeing religious persecution in their homeland (Harmstorf, 2001). Substantial German migration to other Australian colonies also took place: Approximately 4000 Germans immigrated to New South Wales between 1848 and 1857. Wilhelm Kirchner, a Sydney-based German merchant and the colony's migration agent, was instrumental in organising two successful assisted immigration campaigns in Germany (Tampke, 2001).

In Queensland German settlement commenced in 1838. As in the other colonies many settlers headed to rural areas. After the separation from New South Wales on 6 June 1859, a steady stream of assisted German immigrants flowed into Queensland. The 1891 census showed 14,910 Germans in Queensland; this number, however, had decreased to only 12,000 by 1911 (Corkhill, 2001).

Victoria also had a small assisted migration scheme, and by the end of the 1860s the number of assisted migrants who had settled in Victoria was roughly the same as for New South Wales. The overall number of German immigrants in Victoria in the 1850s and early 1860s was considerably higher than in New South Wales due to the gold rush attracting many unassisted immigrants, and settlers from the other colonies (Borrie, 1954; Tampke, 2001).

The gold rush of the 1850 changed the size and composition of Australian immigration. Population trebled in the decade from 1850-60 (Borrie, 1954; Markus, Jupp, McDonald, 2009). Australia now also hosted non-European immigrants which included South Pacific Islanders employed in the Queensland sugar cane plantation industry as cheap labour and a sizeable number of Chinese who arrived in Australia during the gold rush who, compared to the European migrants, faced considerable racism in the form of restrictions and regulations. It has been argued that these restrictions were initially also part of a class struggle that had the unions fighting against employers undercutting local wages by hiring immigrants as cheap labour; but by the end of the 19th an emerging Australian nationalism and the fear of an Asian invasion had replaced class struggle (Vasta, 2006). This is most clearly reflected in the Immigration Restriction Act of 1901, better known as the 'White Australia Policy', one of the first pieces of legislation enacted by the newly federated Commonwealth of Australia comprising the former self-governing British colonies of New South Wales, Queensland, South Australia, Tasmania, Victoria and Western Australia, in 1091.

The Immigration Restriction Act 1901 enabled denial of entry or removal of unwanted persons and general restriction of migration.

The possibly most well-known component of the White Australia Policy was the so-called dictation test, set to exclude unwanted migrants. This test required a prospective migrant to pass a written dictation test. The language of the test, nominated by an immigration officer, often was one the applicant was not familiar with and had been chosen for that reason.

German migration to Australia remained strong until the end of the century. Migration networks, social unrest and poverty in Europe, Australia's perceived opportunities and the decrease in the length of the journey with the invention of the steam ship all contributed. By century's end, however, German expansion and the improvement in the standard of living in Germany all but ended immigration to Australia (Tampke, 2001).

The outbreak of the First World War in 1914 not only put a complete stop to German immigration, it also took a substantial toll on the existing German-Australian community. Anti-German sentiment in Australia was unexpectedly fierce (Perkins, 2001): Until the declaration of war the Germans had been seen as model immigrants creating feelings of kinship and reinforcing the acceptability of German immigrants (Jupp, 1966; Schmortte, 2005).

Legislative and administrative measures introduced to neutralise the German threat resulted in the internment of around 14 per cent of the German population of Australia. After the defeat of Germany in 1918, 696 German citizens 
were deported, and 4,620 volunteered for repatriation to Germany (Perkins, 2001).

As can be seen in the table below, following the First World War, a sharp decline in number of German immigrants could be observed. Factors in the dispersal of the German population other than deportation were assimilation through intermarriage, a decline in the birth rate and an aging population (Kwiet, 2001).

Table 1: Number of Germans in Australia from 1856-1947

\begin{tabular}{|c|c|c|c|c|c|c|c|}
\hline $\begin{array}{c}\text { Colony (state)/ } \\
\text { Year }\end{array}$ & NSW & Vic & Qld & SA & WA & Tas & Australia \\
\hline $\mathbf{1 8 6 1}$ & 5467 & 10418 & 2124 & 8863 & na & na & $\mathbf{2 6 8 7 2}$ \\
\hline 1871 & 6614 & 8995 & 8317 & 8309 & na & na & $\mathbf{3 2 2 3 5}$ \\
\hline 1881 & 7521 & 8571 & 11638 & 8801 & 71 & 782 & 37384 \\
\hline 1891 & 9565 & 10764 & 14910 & 8514 & 290 & 918 & 44961 \\
\hline 1911 & 7241 & 6142 & 11979 & 4977 & 2036 & 590 & 32990 \\
\hline 1921 & 4569 & 3693 & 9527 & 3193 & 1005 & 387 & $\mathbf{2 2 3 9 6}$ \\
\hline 1933 & 3595 & 2855 & 6983 & 2149 & 996 & 238 & 16842 \\
\hline 1947 & 4457 & 4307 & 3839 & 1098 & 656 & 171 & 14567 \\
\hline
\end{tabular}

Source: Adapted from: Borrie $(1954$, p. 158)

The Second World War is considered a watershed for Australia, bringing into sharp focus fears regarding Australia's isolation and Britain's inability to defend the country. With it came the realisation that Australia needed a larger population for defence purposes but also for political and economic reasons: a small population meant a small economy, which would make Australia vulnerable in an unpredictable political world. Post-war planning set an annual growth target of two per cent, half of this to be achieved through migration.

The Federal Department of Immigration was established in July 1945. Arthur Calwell, the first Minister for Immigration, oversaw the commencement of the Australian post-war migration program; a program maintained and refined to take account of changing economic, social and political environments, by each succeeding Australian government. The initial program under the slogan 'populate or perish' offered assisted passage and work contracts to selected migrant groups (Richards, 2008). Initially, in keeping with the White Australia Policy, Australia's post-war immigration program was geared towards British, European and later American immigration. However, in line with changing macro political and economic realities, race based migrant selection was replaced step by step with selection criteria based on Australia's population and economic development needs.

As part of the 'populate or perish' initiative, the Australian government signed an agreement with the Federal Republic of German launching large-scale post war German migration in 1952. The initial agreement was valid for five years and was followed by two further agreements, finally terminated in 1981 (Buchanan, 2007).

Factors that assisted the acceptance of German mass migration only a few years after the end of the Second World War despite initial concern on the part of the Australia populace included the bi-partisan agreement on population targets (Richards, 2008), the aim of the program, creation of a desirable mix of North-Western Europeans to offset Southern European migration, the promise of security screening and migrants as labour for those sections of the economy that required it (Sauer, 1999). Sauer argues further that the Government used Australian self-interest to shape perceptions by concentrating on the economic dimension and emphasising German trade skills as an asset to Australian economy.

Other factor cited are the existence and clever exploitation of the common stereotype of Germans as industrious, loyal and skilled migrants, who assimilated well and could be instrumental in advancing Australia's economy (Sauer, 1999; Schmortte, 2005). Kaplan's investigation of the media's role in reviving the stereotype of the useful German over the Nazi cliché concludes that the media was instrumental in making German migrants acceptable again. Moreover, ideological reasons, the Germans were seen as anti-communist, may also have contributed to the re-acceptance of Germans (Kaplan, 1995).

According to Khoo, Hugo and McDonald (2008), three major periods can be identified in the Australian migration policy context:

1947-1971: The substantial labour shortage in the post-war period caused unprecedented immigration levels and extension of the migration program from Britain to other European countries to satisfy Australia's workforce needs. The labour market needs of the so-called Long Boom were predominantly for unskilled and semi-skilled labour, similar to 
European labour market needs. Unlike the European guest worker programs of the same period, the focus of Australia's migration program was on settlement migration.

1971-1996: The end of the Long Boom and the ageing of the baby boomers resulted in structural change to the economy. As part of these changes, the Immigration Restriction Act was repealed in 1973. The focus of the migration program shifted from labour shortages to skills requirements and lead to the introduction of the prototype of Australia's current three stream-skills, family, and humanitarian stream - migration. This period also saw significant immigration from Asian countries.

1996-present (2008): The skills focus of Australian immigration policy increased. The major change to immigration policy can be found in the shift from the permanent settlement focus to temporary migration. In 1996 in response to the new global economy and business groups' request for more flexible arrangement to facilitate employment of overseas skilled labour if unavailable in Australia, new temporary business entry visas allowing employers to sponsor workers for up to four years were introduced.

Unlike in the migration program where migrant numbers are decided in the year prior, there is no limitation on the number of temporary visas per year. Since the introduction of temporary visas, there has been a steady increase in temporary entry of skilled workers, students and working holiday makers. The first two categories are of particular interest because they allow for a direct reaction to economic developments on the one hand but have also become a pool for recruitment for employer sponsored migration. As Australia allows for onshore change in visa status, temporary entry is seen as pathways to permanent settlement.

In 2012, further refinement of the migration program resulted in a new process where potential migrants lodge an expression of interest with the Australian Government/DIAC who will assess these expressions and then invite suitable applicants to submit visa applications.

\section{Some statistical data relating to German migration and return to and from Australia}

As shown in the Figure 1, the number of Germans in Australia in 1947 was just 14,567, equating to 0.2 per cent of the population, the lowest percentage since 1830 (Kaplan, 2001). With the commencement of German mass migration in 1952 numbers started to increase steadily. Results were first reflected in the 1954 census figures: 65,422 Germans had immigrated. By 1961 Australia's German migration population had reached 109,315 persons or one per cent of the population. Eighty four per cent of these arrivals were assisted passage migrants. After 1961 the German population numbers stabilised; in 1996 the number stood at 110,331 despite 30 per cent of settlers permanently leaving Australia again in the period 1947-83 (Kaplan, 2001).

From the 1970s onwards, the number of German migrants decreased considerably: from approximately 2000 annually in the 1970s to approximately 850 annually in the early 1990 (Kaplan, 2001). It has been suggested that the reasons for this decline may be found in Australian immigration policy, and German and Australian economic conditions (Buchanan, 2007; Kaplan, 2001; Münstermann, 1997).

Table 2: German migration to Australia: settler arrivals, permanent departures, departures as percentage of settler arrival:

\begin{tabular}{|c|c|c|c|}
\hline Year (financial year) & Settler arrivals & Permanent departures & $\%$ \\
\hline $1946-1949$ & 2563 & 747 & 29 \\
\hline $1950-1959$ & 69756 & 7033 & 10 \\
\hline $1960-1969$ & 48952 & 23463 & 48 \\
\hline $1972-1979$ & 18752 & 13158 & 70 \\
\hline $1980-1989$ & 28925 & 11359 & 39 \\
\hline
\end{tabular}

Source: Adapted from Muenstermann (1997, p. 63A)

Table 3: German migration to Australia: settler arrivals, permanent departures, permanent departures as percentage of settler arrivals, 1990-2001 and 2001-2012

\begin{tabular}{|c|c|c|c|}
\hline Year(financial year) & Settler arrivals & Permanent departures & $\%$ \\
\hline $1990-2001$ & 8637 & 2423 & 28 \\
\hline $2001-2012$ & 9379 & 4368 & 47 \\
\hline
\end{tabular}

Source: Adapted from DIMA/DIAC statistical sources $(2006,2007,2011,2012)$ 
German interest in Australia as a migration destination has remained strong over the last 30 years (Buchanan, 2007). Kaplan (2001) states that the Australian Immigration office in West Germany received approximately 20,000 enquiries annually during the 1980s. This interest in the 1980s might have been influenced by the European socio-political situation, such as the fear of a nuclear threat in some sectors of the German population, growing unemployment, overcrowded cities, and high cost of housing among others (Harmstorf \& Cigler, 1985). Another factor consistently cited by those who have experienced Australia especially as a holiday destination, is the attraction of Australia's climate and landscape in conjunction with cheap airfares, making Australia accessible (Buchanan, 2007; Harmstorf \& Cigler, 1985).

The excerpt from the Current Country Rankings of the Department of Immigration and Citizenship for the period 2011-2012 below provides an overview of Germany's position in relation to other migrant country streams.

Table 4: Except from DIAC's Current Country Rankings showing Germany's ranking

\begin{tabular}{|c|c|c|c|c|c|c|c|}
\hline $\begin{array}{c}\text { Strea } \\
\mathrm{m}\end{array}$ & $\begin{array}{c}\text { Family } \\
\text { Stream }\end{array}$ & $\begin{array}{c}\text { Employer } \\
\text { Sponsored }\end{array}$ & $\begin{array}{c}\text { Total Skill } \\
\text { Stream }\end{array}$ & $\begin{array}{c}\text { Studen } \\
\text { ts }\end{array}$ & $\begin{array}{c}\text { Business (Long } \\
\text { Stay) }\end{array}$ & Visitors & $\begin{array}{c}\text { Population in } \\
\text { Australia }\end{array}$ \\
\hline Rank & 19 & 11 & 17 & 18 & 10 & 8 & 10 \\
\hline
\end{tabular}

Source: adapted from DIAC, Current Country Rankings (2013)

This inflow, however, is accompanied by a sizeable outflow of permanent German migrants from Australia. For the financial year 2011-2012, the last year data is available, the Department of Immigration and Citizenship reports 837 settler arrivals compared to 537 permanent departures, a departure rate of 64 per cent.

Table 5: Permanent Departures Overseas Born by Selected Country of Birth by Length of Stay - Financial Year 2011-12

\begin{tabular}{|c|c|c|c|c|c|c|c|}
\hline $\begin{array}{c}\text { Country of } \\
\text { birth }\end{array}$ & $<2$ years & $\begin{array}{c}2 \text { and }<3 \\
\text { years }\end{array}$ & $\begin{array}{c}3 \text { and }<4 \\
\text { years }\end{array}$ & $\begin{array}{c}4 \text { and }<5 \\
\text { years }\end{array}$ & $5+$ years & Not stated & Total \\
\hline Germany & 70 & 35 & 20 & 27 & 374 & 11 & 537 \\
\hline
\end{tabular}

Source: DIAC (2013)

In an immigration country like Australia, departure of settler migrants is not an uncommon phenomenon-the Australian Department of Immigration and Citizenship (DIAC) puts the percentage of overseas born residents departing permanently as a proportion of total permanent departures at approximately 50 per cent since 1998-99 (DIAC, 2011, p. 1). In 2011-12 of the 87,493 people who indicated they were departing permanently, 51.1 per cent were born overseas, a slight increase on the 2010-11 proportion of 50.2 per cent.

\section{Issues associated with investigating and analysing migration trajectories and return migration}

An investigation into return migration is faced with two significant issues: data availability and quality, and how to define return migration.

The weak statistical basis due to different data collections methods between countries, difficulties in acquiring data and data distortion issues has been identified as one of the major challenges to progress in the area (Dumont \& Spielvogel, 2008; Ette \& Sauer, 2010). This assessment is shared by migration scholars across the field and despite substantial improvements still persists today (Cassarino, 2004; Dumont \& Spielvogel, 2008; Ette \& Sauer, 2010).

In the context of statistical data collection on permanent departures from Australia, the Australian Department of Immigration and Citizenship cautions on its website that its statistics are representative of trends only as the data is based on information provided by passengers leaving the country and who may not provide correct or truthful answers on their passenger cards. (DIAC, 2013)

Similarly, historical statistical data on German immigration can only provide trends as the classification for migrants entering the country was changed a number of times leading to different definitions of who counted as German. The Department of Immigration and Multicultural Affairs in one of its publications provides the following advice:

"The data for Germany are inflated because data prior to 1959 are based on country of last residence, and most

immigrants arriving from Germany after World War Two were displaced persons who were not born in Germany. 
Settler arrivals by birthplace data not available prior to 1959. For the period July 1949 to June 1959, Permanent and Long Term Arrivals by Country of Last Residence have been included as a proxy for this data. When interpreting this data for some countries (DIMA, 2001, pp. 24-25)."

The second issue is the lack of a common definition and coherent terminology for the concept of return migration. The reason may be related to the fact that theoretical approaches to migration were have long conceptualised migration as one discrete move from country of origin to host country. The view of migration as a permanent event may have been influenced by a focus on the transatlantic mass migration of the early 20th century, however it has been shown that even then about a quarter of migrants returned. More recent approaches to migration and return migration research such as transnationalism and social network theory view return as part of the migration cycle (Dumont \& Spielvogel, 2008) or as a subset of temporary migration (Dustmann \& Weiss, 2007).

On the most basic level, return migration involves movement of a person through space and time. These are, of course, only points on a continuum and there other dimensions, such as the legal/administrative dimension involving the question of voluntary, assisted or forced return. The observed return may also be part of a much more complex series of movements and may include multiple exits and entries to the same or different countries.

\section{Data collection and preliminary results}

The approach taken in this project is qualitative because qualitative approaches recognise the importance of the subjective creation of meaning while at the same time not discarding any notion of objectivity (Hesse-Biber, 2010). The approach centres on micro-level data collected through semi-structured interviews, supplemented by secondary quantitative census and migration statistics data to situate the micro-level narratives in the macro-level dimension.

At the time of writing the data collection phase is ongoing. Interviews so far have been predominantly conducted in Australia; two interviews have been conducted via Skype with returnees in Germany.

Due to the nature of the study a non-random, non-probability sampling strategy was chosen. The method used is purposive sampling since the participants for the study needed to fulfil the following criteria:

- in Australia: be a long-term (12 months or longer) Australian resident of German citizenship/ancestry in Australia

○ who has contemplated and rejected return, or

o intends to return, or

o intends to return and has already made preparations

- in Germany: be a returned long-term Australian resident of German citizenship/ancestry in Germany (duration of stay in Germany at least 12 months)

To add an organisational dimension, representatives of organisations involved in cross-cultural German-Australian endeavours were also approached for interviews.

Advertisements in German language media resulted in the recruitment of a small number of interview partners. The majority of participants were recruited via the snowballing method as the originally recruited interviewees then referred other interested Germans to the project.

As mentioned above, the interview phase is yet to conclude; however, it is possible to say that considerable temporary and repeat migration can be observed. Other areas of interest not yet fully explored include assimilation, acculturation and identity and the question of language maintenance.

\section{Conclusion}

Migratory flows can have a significant socio-economic and political impact on sending and receiving countries. In an immigration country such as Australia with one of the most regulated migration programs in the world, return migration is an issue of importance. Apart from the fact that in the case of settler migration, return represents a loss of human capital to Australia after its investment in the recruitment and selection of migrants, there are also policy implications as return can lead to unplanned changes in the composition of the immigrant population. Thus, return migration can impact on planning and It can also have a significant social and cultural impact by affecting the composition of the net gain from migration. The characteristics of a settler departing are different to those of one arriving, resulting in different needs and contributions. Moreover, immigrant numbers are not unrestricted, a settler who departs might do so at the expense of somebody who would have staid and provided a sustained contribution to Australia.

On the other hand, return migration can establish links between countries, fostering closer relations which can 
facilitate access to markets, and allow for the acquisition and circulation of knowledge and skills.

After the conclusion of the data collection, major themes will be analysed with a view to establishing trends in return behaviour and associated determinants; the processes involved and the possible effect on home and host societies.

\section{References}

Australian Bureau of Statistics (2012). Cultural Diversity in Australia - Reflecting a Nation: Stories from the 2011 Census. Canberra: Australian Bureau of Statistics Retrieved on 18 June 2013 from http://abs.gov.au/ausstats/abs@.nsf/Lookup /2071.0main+features902012-2013.

Borrie, W.D. (1954). Italians and Germans in Australia: a study of assimilation. Melbourne, Vic: Cheshire for Australian National University.

Buchanan, S.E. (2007). The Construction of Cultural Identity: Germans in Melbourne. Berlin: Litverlag Dr. W. Hopf

Cassarino, J-P. (2004). Theorising Return Migration: the Conceptual Approach to Return Migrants Revisited. IJMS: International Journal on Multicultural Societies, vol 6: 253-279.

Corkhill, A. (2001). German Settlement in Queensland 1838-1939. In: Jupp, J. (Ed) The Australian people: an encyclopedia of the nation, its people and their origins. Melbourne, Vic: Cambridge University Press, 369-370.

Department of Immigration and Citizenship (2013). Current Country Ranking. Barton, ACT: Commonwealth of Australia. Retrieved on 18 June 2013 from http://www.immi.gov.au/media/statistics/country-profiles/_pdf/country-ranking.pdf.

Department of Immigration and Citizenship (2012). Permanent Departures Overseas Born by Selected Country of Birth by Length of Stay - Financial Year 2011-12. Retrieved on 18 June 2013 from: http://www.immi.gov.au/media/statistics/statisticalinfo/oad/perm-dep/permdep.htm.

Department of Immigration and Citizenship (2011) Trends in migration 2010-2011. Barton, ACT: Commonwealth of Australia.

Department of Immigration and Citizenship (2011). Emigration 2010-2011 Australia. Barton, ACT: Commonwealth of Australia.

Department of Immigration and Citizenship (2007). Emigration 2005-2006 Australia. Barton, ACT: Commonwealth of Australia.

Department of Immigration and Multicultural Affairs (2006). Settler Arrivals 1995-96 to 2005-06, Australia, States and Territories. Barton, ACT: Commonwealth of Australia.

Department of Immigration and Multicultural Affairs (2001). Immigration: Federation to Century's End. Belconnen, ACT: Commonwealth of Australia.

Dumont, J.-C. \& Spielvogel, G. (2008). Return Migration: a New Perspective. OECD International Migration Outlook. Annual Report 2008 Edition. (pp. 162 -222). Paris.

Dustmann, C. \& Weiss, Y. (2007). Return Migration: Theory and Empirical Evidence. British Journal of Industrial Relations, vol. 45, no. 2, pp. 236-256.

Ette, A., \& Sauer, L. (2010). Auswanderung aus Deutschland. Daten und Analysen zur international Auswanderung deutscher Staatsbuerger. Wiesbaden: VS Verlag fuer Sozialwissenschaften.

Harmstorf, I. (2001). German Settlement in South Australia until 1914. In J. Jupp (Ed.), The Australian people: an encyclopedia of the nation, its people and their origins (pp. 360-365). Melbourne: Cambridge University Press.

Harmstorf, I., \& Cigler, M. (1985). The Germans in Australia. Melbourne: AE Press.

Hesse-Biber, S. (2010). Qualitative Approaches to Mixed Methods Practice. Qualitative Inquiry, 16(6), 455-468. doi: 10.1177/1077800410364611.

Jupp, J. (1966). Arrivals and Departures. Melbourne, Vic: Landsdowne Press Pty Ltd.

Markus A, Jupp, J., McDonald, P. (2009). Australia's Immigration Revolution. Sydney, NSW: Allen \& Unwin.

Jupp, J. (2007). From White Australia to Woomera: the story of Australia immigation (2nd ed.). New York: Cambridge University Press.

Kaplan, G. (1995). From 'Enemy Alien' to Assisted Immigrant: Australian Public Opinion of Germans and Germany in the Australian Print Media, 1945 - 1956. In M. Jürgensen (Ed.), German-Australian cultural relations since 1945: proceedings of the conference held at the University of Queensland, Brisbane from September 20-23, 1994 (pp. 78-100). Berne: Peter Lang AG, European Academic Publishers.

Kaplan, G. (2001). Post-War German Immigration. In J. Jupp (Ed.), The Australian people: an encyclopedia of the nation, its people and their origins (pp. 377-379). Melbourne, Vic: Cambridge University Press.

Khoo, S-E, Hugo, G. \& McDonald P. (2008). Which Skilled Temporary Migrants Become Permanent Residents and Why? International Migration Review 42: 193-226.

Kwiet, K. (2001). Inter-War German Communicty Life. In J. Jupp (Ed.), The Australian people: an encyclopedia of the nation, its people and their origins (pp. 372-375). Melbourne, Vic: Cambridge University Press.

Münstermann, I.K.R. (1997). German Immigrants in South Australia After 1945. (Unpublished doctoral dissertation). Flinders University of South Australia, Adelaide, South Australia.

Perkins, J. (2001). Germans in Australia during the First World War. In J. Jupp (Ed.), The Australian people: an encyclopedia of the nation, its people and their origins (pp. 370-372). Melbourne, Vic: Cambridge University Press.

Richards, E. (2008). Destination Australia: migration to Australia since 1901. Sydney, NSW: University of New South Wales Press Ltd.

Sauer, A. (1999). Model Workers or Hardened Nazis? The Australian Debate about Admitting German Migrants, 1950 -1952. Australian 
Journal of Politics and History, 45(3), 422-437.

Schmortte, J. (2005). Attitudes towards German immigration in South Australia in the post-Second World War Period, $1947-60$. Australian Journal of Politics and History, 51(4), 530-544.

Tampke, J. (2001). Pre-War German Settlement in Eastern Australia. In J. Jupp (Ed.), The Australian people: an encyclopedia of the nation, its people and their origins (pp. 365-369). Melbourne: Cambridge University Press.

Tampke, J. (2006). The Germans in Australia. New York: Cambridge University Press.

Vasta, E. (2006). Migration and Migration Research in Australia. In E. Vasta \& V. Vuddamalay(Eds.) International Migration and the Social Sciences: Confronting National Experiences in Australia, France and Germany. Basingstoke: Palgrave Macmillan. 